\title{
En snarvei i diagnostikken av personlighetsforstyrrelser?
}

Innføring av pakkeforløp for en rekke lidelser er gjennom standardisert utredning og behandling tenkt å sikre et effektivt og likeverdig tilbud. Det kan medføre økt bruk av screeninginstrumenter i diagnostisk arbeid. Hvilken rolle bør screeninginstrumenter spille i utredningen av komplekse og heterogene lidelser som personlighetsforstyrrelser?

Personlighetsforstyrrelser omfatter vedvarende atferdsmønstre som kommer til uttrykk gjennom rigide reaksjoner på et bredt spekter av personlige og sosiale situasjoner. De representerer betydelige avvik i hvordan man opplever, tenker, føler og forholder seg til andre individer (1).

Forekomsten av personlighetsforstyrrelser varierer innenfor normalbefolkningen mellom $5 \%$ og 14,8\% (2). Innenfor en populasjon av psykiatriske pasienter varierer forekomsten fra $45,2 \%$ til $80 \%(3,4)$. Prevalensen er altså svært avhengig av populasjonen man undersøker.

\section{Screeninginstrumenter for personlighetslidelser}

Ulike instrumenter er blitt undersøkt internasjonalt, blant annet Standardised Assessment of Personality-Abbreviated Scale (SAPAS) og Iowa Personality Disorder Screen (IPDS) $(5,6)$. Med en sensitivitet og spesifisitet på rundt $80 \%$ konkluderte Germans og medforfattere at de ovenstående screeninginstrumentene er brukbare i en tostegs diagnostisk prosedyre på en populasjon i psykiatrisk poliklinikk, hvor man grovselekterer den gruppen pasienter som må utredes ytterligere (7).

I Norge er IPDS et av få screeninginstrumenter som er validert $i$ en poliklinisk populasjon. Med en sensitivitet på $77 \%$ og spesifisitet på $71 \%$ konkluderer Olssøn og medarbeidere med at instrumentet er mindre nøyaktig enn angitt $\mathrm{i}$ internasjonale studier, men likevel nyttig som screeninginstrument til bruk i psykiatriske poliklinikker (8).

Screeningtester blir validert i spesifikke pasientpopulasjoner. Dersom testen benyttes i en annen populasjon, må man være klar over at testens sensitivitet og spesifisitet er avhengig av forekomsten av lidelsen i en spesifikk populasjon. Man kan derfor ikke overføre resultater fra en valideringsstudie til en ny populasjon med en annen prevalens.

Sannsynlighetsratio (likelihood ratio LR) er uavhengig av prevalens (9). LR+ angir hvor mye sjansen for å ha en personlighetsforstyrrelse øker, når en test er positiv. Internasjonale studier viser at LR+ for brukte screeninginstrumenter for personlighetsforstyrrelser ligger mellom 3,5 og 5,1 . Det betyr at et positiv testresultat kun gir en moderat økning i sannsynligheten for personlighetsforstyrrelse (7). Siden IPDS i Norge har lavere sensitivitet og spesifisitet enn i internasjonale studier, medfører det at sannsynlighetsratio er lavere enn 5,1.

En sannsynlighetsratio på 5,1 gir en økning fra $12 \%$ til $43 \%$ sannsynlighet for å ha personlighetsforstyrrelse ved en positiv

\section{«Screeningtester blir validert i spesifikke pasientpopulasjoner»}

test i den generelle befolkningen, som fortsatt betyr at pasienten har større sannsynlighet for ikke å ha en personlighetsforstyrrelse (7). Testen er derfor ikke egnet for screening av personlighetsforstyrrelser i den generelle befolkningen.

\section{Bruk hodet - \\ ikke screeninginstrumentet}

Finnes det en snarvei til diagnosen personlighetsforstyrrelse? Screeninginstrumenter for personlighetsforstyrrelse viser en tilfredsstillende sensitivitet og spesifisitet $i$ en populasjon hvor forekomsten er ca. 50\%, eksempelvis i en psykiatrisk avdeling eller ved et distriktspsykiatrisk senter (DPS). Men på grunn av lav sannsynlighetsratioverdi vil det ikke fungere $i$ andre populasjoner. Nasjonalt og internasjonalt jobbes det med å utvikle screeninginstrumenter for personlighetsforstyrrelser som kan fungere i ulike populasjoner.

I en hektisk hverdag kan det virke besnærende å bruke ulike screeninginstrumenter for rask diagnostikk. Det er derfor av stor betydning at den enkelte kliniker har robust kunnskap om fordeler og ulemper ved screening for ulike lidelser i ulike populasjoner.

\section{Sara Germans Selvik \\ Sara.Germans@hnt.no \\ Olav Kristiansen \\ Benjamin Hummelen \\ Hanne Indermo Solhaug}

Sara Germans Selvik (f. 1972) er ph.d., spesia-

list i psykiatri ved Psykiatrisk klinikk, Sykehuset Namsos, leder av referansegruppe for Nasjonal tjeneste for personlighetspsykiatri og førsteamanuensis ved Norges teknisk-naturvitenskapelige universitet, Trondheim.

Forfatter har fylt ut ICMJE-skjemaet og oppgir ingen interessekonflikter.
Olav Kristiansen (f.1957) er spesialist i psykiatri ved Psykiatrisk klinikk, Sykehuset Namsos. Forfatter har fylt ut ICMJE-skjemaet og oppgir ingen interessekonflikter.

Benjamin Hummelen (f.1967) er ph.d. og seniorforsker ved Avdeling for forskning og utvikling, Forskergruppe personlighetspsykiatri, Oslo universitetssykehus.

Forfatter har fylt ut ICMJE-skjemaet og oppgir ingen interessekonflikter.

Hanne Indermo Solhaug (f.1981) er konstituert overlege i psykiatri ved Psykiatrisk klinikk,

Sykehuset Namsos.

Forfatter har fylt ut ICMJE-skjemaet og oppgir ingen interessekonflikter.

Litteratur

1. Verdens helseorganisasjon (WHO). International Classification of diseases (tenth edition) (ICD-10). www.who.int/classifications/icd/en/ (14.3.2016).

2. Samuels J, Eaton WW, Bienvenu OJ 3rd et al. Pre valence and correlates of personality disorders in a community sample. Br J Psychiatry 2002; 180 $536-42$

3. Verheul R, Van Den Brink W. Persoonlijkheidsstoornissen. I: De Jong A, Van Den Brink W, Ormel J et al, red. Handboek psychiatrische epidemiologie. Maarssen: Elsevier/De tijdstroom, 1999: 347-372.

4. Andermann A, Blancquaert I, Beauchamp S et al. Revisiting Wilson and Jungner in the genomic age a review of screening criteria over the past 40 years. Bull World Health Organ 2008; 86: 317-9.

5. Moran P, Leese M, Lee T et al. Standardised Assessment of Personality - Abbreviated Scale (SAPAS): preliminary validation of a brief screen for personality disorder. Br J Psychiatry 2003; 183 $228-32$.

6. Langbehn DR, Pfohl BM, Reynolds $S$ et al. The lowa Personality Disorder Screen: development and preliminary validation of a brief screening interview. J Pers Disord 1999: 13: 75-89.

7. Germans S, Van Heck GL, Hodiamont PPG. Results of the search for personality disorder screening tools: clinical implications. J Clin Psychiatry 2012 73: $165-73$

8. Olssøn I, Sørebø Ø. Dahl AA. A cross-sectional testing of The lowa Personality Disorder Screen in a psychiatric outpatient setting. BMC Psychiatry 2011; 11: 105-13.

9. Pauker SG, Kassirer JP. Therapeutic decision making: a cost-benefit analysis. N Engl J Med 1975; 293: 229-34.

Mottatt 16.2. 2016, første revisjon innsendt 6.3. 2016, godkjent 14.3. 2016. Redaktør: Ketil Slagstad.

Publisert først på nett. 